\title{
Student Perception of Using Google Classroom in Mathematics Learning In Covid-19 Pandemic
}

\author{
Ulum Fatmahanik \\ Islamic State Institute (IAIN) Ponorogo, East Java \\ \{ulum.fatma@gmail.com\}
}

\begin{abstract}
COVID-19 pandemic forced the education sector to make a learning system change from face to face to online to break the chain of distribution of COVID-19. This requires lecturers and students to adapt to changes in how to deliver content using online learning. The google classroom application was chosen in conducting in mathematics learning lecturers because this application allows the creation of classrooms online. The purpose of this research is to explore students' perceptions in terms of 1) ease of use of google classroom, 2) ease of understanding of material using google classroom, 3) effectiveness of google classroom in learning and 4) obstacles experienced by students during learning using google classroom. The research method used was descriptive qualitative using survey techniques with instruments in the form of questionnaires and interviews distributed using Google Form. The results showed that $59.25 \%$ of students agreed to the ease of use of google classroom, $57.13 \%$ agreed to the ease of understanding of the material, and $63.94 \%$ agreed to the effectiveness of google classroom. As for the obstacles experienced by $48.57 \%$ of unstable networks; $30.43 \%$ quota limitations; $5.30 \%$ difficult to focus and $15.77 \%$ other obstacles. But in general google classroom is effectively used in the process of teaching mathematics learning and can be used as an alternative in online learning. But it would be better if combined with other learning platforms and face-to-face learning.
\end{abstract}

Keywords: Student Perception; COVID-19 Pandemic; Google Classroom; Mathematics Learning

\section{Introduction}

Corona Virus Disease 2019 (Covid-19) originating from Wuhan, Hubei Province, China has spread rapidly throughout the world. On March 11, 2020, the World Health Organization (WHO) even declared this event a global pandemic [1, pp. 157-160]. Likewise, Indonesia first stated the corona case entered this country on March 13, 2020. So that requires that we do quarantine independently at home to break the chain of the spread of the virus. This situation causes all activities in various sectors to be hampered, one of which is in the education sector. To overcome this pandemic, new policies have been formed; social distancing, work from home, learning from home to lockdown for affected countries, including for Indonesia [2]. 
Indonesia became one of the countries affected by the 19th pandemic, which in its development is increasingly spreading rapidly to many regions in Indonesia. Currently, there are a total of 197 countries that have closed schools. While other countries such as Asia, Africa, the Middle East, Europe, North America, and South America have imposed restrictions on learning activities in schools and universities, namely by conducting online learning [3, pp. 2176-4446]. The COVID-19 pandemic has influenced all levels of the education system in Indonesia, from the elementary level to the tertiary level. That then becomes a challenge for all people in the world. So that all countries are moved to make policies in anticipation of slowing and preventing the spread of the COVID-19 virus. In the field of education, all countries strive to make the best policies for the integrity of education services. Online Learning in the Middle of the Covid-19 Pandemic, the Challenging Maturity [4].

IAIN Ponorogo as a university has also taken preventive measures to protect and break the chain of distribution of COVID 19 for all students, lecturers, and staff from the transmission of the coronavirus by conducting online lecture processes and of course this has forced lecturers to have to adapt to changes in how to deliver content by using various learning modes based on online learning or E-learning [5].

Online-based learning was chosen as alternative learning by all educators around the world especially in the current Covid-19 pandemic because online learning can facilitate wider and distance learning. Through the facilities offered and provided by the online learning platform so that learning can take place anywhere and anytime without any limits on space, time, or distance. Online or online learning is done through various applications that can support the learning process starting from face-to-face applications such as zoom, google meet, and other online media platforms such as google classroom, WhatsApp group, etc.

The result is a surge in traffic and users of online learning platforms significantly. This can be seen from the data compiled by the Daily Social which noted the Quipper platform has increased 30-fold over the past week after the implementation of home learning on March 16, 2020. Kelase platform has increased 10 times with the number of users $33 \%$. Besides, Telkomsel also recorded a $16 \%$ increase in broadband traffic dominated by an increase in the use of teacher space platforms, campus e-learning, and google classroom which skyrocketed to $54.04 \%$. While Zenius platform service traffic on the Tri Indonesia network rose $73 \%$, Teacher Room 73\%, Quipper 19.6\%, and Edmodo 84.1\% [6].

The google classroom application was chosen to assist students and lecturers in conducting online lectures in mathematics learning lectures during the COVID-19 pandemic. Google classroom is an application that allows the creation of classrooms online. Google Classroom can be a means of distributing tasks, gathering tasks, and even assessing the tasks that have been collected. Also, Google classroom provides discussion forum features so that lecturers can open a class discussion that can be responded to and comment on such as commenting activities on Facebook [7] Besides, Google classroom can be said as one of the learning media based on inquiry learning methods because google classroom can involve students' abilities to the maximum in finding, understanding, investigating, analyzing and formulating learning outcomes [8].

In improving the workflow of Google Classroom teachers, it is considered as one of the best platforms. Because this application provides a set of advanced features that make it an ideal tool for students to use. This application also saves time, keeps classes organized, and improves communication with students. This application is available for everyone with Google Apps for Education, a free suite of productivity tools including Gmail, Drive, and Docs[9, pp. 12-18]. Google classroom is useful in facilitating the teaching and learning 
process, so students can use it easily whenever needed [10, pp. 5-8]. Some features that can be used in the learning process using google classroom include class preparation, the main page that can be used to display student assignments, can be accessed using a smartphone, storing data on Google Drive, adding a profile picture. Also, other features can be used by lecturers in developing learning material, namely creating questions, creating assignments, and creating topics. One of the features that will often be used by lecturers in using google classroom is to create assignments that function to give assignments to students. Also, some features create topics that can be used to create lecture topics that will be discussed in virtual classes. There are even Google Meet features that can be used by lecturers and students if you want to do face-to-face meetings directly using virtual classes.

Google Classroom makes it easy to create and provide paperless lecturer assignments for students. Assignments in the form of documents or videos and discussions. It also can do tests and quizzes online using the Google form format with various types of questions [11, pp. 246255]. Also, google classroom does not contain advertising elements, so it is safe to use, Google classroom is free [12, pp. 60-79]. This free Google classroom is provided for educational institutions (schools), nonprofits, and individuals[13, pp. 39-46].

The results of the research by Idad Suhada et al showed that the application of google classroom in online learning during the COVID-19 outbreak was quite good and effective [14]. These results are reinforced by research Ahmad Rusdiana, Moh. Sulhan, Isep Zaenal Arifin Invite Ahmad Kamludin which states that the application of the Blended Learningbased POE2WE model with google classroom media can be used as a solution to the problem in the WFH Pandemic Covid-19 learning process [4] the feasibility of google classroom as a learning medium shows the average results of the validation are very good, so it can be said to be feasible as a learning medium[15] learning motivation and learning outcomes are quite good after the implementation of google classroom [16] and google classroom can develop a better understanding for students[17, pp. 112-123].

Also, research conducted by Ida Farida, Risa Rahmawati Sunarya, Riri Aisyah, Imelda Helsy [18] also showed that the majority of students carried out online chemistry learning well. The level of participation and enthusiasm of students to master learning content, work assignments, and online exams is quite high. In terms of understanding, not all students can adapt to access chemistry learning content well. Students experience difficulties with chemical content related to calculations, reactions, and submicroscopic representations.

Based on the explanation above, this study aims to explore how students' perceptions in online learning using google classroom in terms of 1) perceptions of student convenience in using google classroom, 2) perceptions of student ease in understanding material using google classroom, 3) effectiveness of google classroom in learning lectures mathematic, 4) obstacles experienced by students in online learning mathematics learning using google classroom.

\section{Research Methodology}

The research method used in this research is descriptive qualitative using survey techniques. The research sample taken was all students majoring in primary teacher Education Ponorogo State Islamic Institute Ponorogo 6th semester who took Mathematics Learning courses with a total of 182 students. The instruments used were questionnaires and online interviews using the google form. Questionnaire questions are arranged by 1) ease of using google classroom, 2) ease in understanding material using google classroom, 3) effectiveness of google classroom in learning lectures mathematic, 4) obstacles experienced by students in 
online learning mathematics learning using google classroom. The answer options are arranged using a Likert scale with a choice of strongly disagree, disagree, agree, and strongly agree. The questionnaire for each question is presented as follows:

Table 1. Question Aspect in Questionnaire Compilation

\begin{tabular}{l} 
Aspect \\
\hline Ease of using google classroom \\
Ease in understanding material using \\
google classroom
\end{tabular}
google classroom

Effectiveness of google classroom in learning lectures mathematic

Obstacles experienced by students in online learning mathematics learning using google classroom

\section{Questionnaire}

I can access google classroom and understand how to use it easily..

Display google classroom is very clear, simple, attractive, easy to understand.

Using the google classroom application task completion and collection becomes more flexible and easier.

earning by using google classroom is easier compared to other applications

The google classroom application makes it easy for me to save material documents and important assignments

Google Classroom makes it easy for me to get announcements or information quickly

Students enjoy using google classroom in learning

understand group discussion through google classroom better than discussion through other applications of Mathematics Learning lectures.

The google classroom application makes me more understanding material in Mathematics Learning lecturers Lectures in Mathematics Learning by using google classroom makes me confused in understanding the material

Using google classroom in Mathematics Learning classes saves more quota compared to face-to-face applications Google Classroom allows me to complete and collect tasks more on time.

Lecturers, actively giving responses, discussions, or assignments during the lecture process in Mathematics Learning lectures

Google classroom application can save time

By using Google Classroom, it allows students to get feedback faster

I have difficulty focusing on mathematics learning courses when using the google classroom application

I always experience quota limitations in mathematics learning courses using the google classroom application The internet network was not stable when I conducted a mathematics learning course using google classroom application

Mention other obstacles that you experience when studying mathematics using google classroom application

\section{Result and Discussion}

After distributing 19 question items in the questionnaire to all respondents in this case the students, then the recapitulation of the results of the questionnaire was conducted. The 
assessment is carried out using a Likert scale with a scale of 1 to 4, namely strongly disagree (1), disagree (2), agree (3), and strongly agree (4). The results obtained from 182 respondents for the ease of use of google classroom in Mathematics Learning lecturer in primary school are as follows:

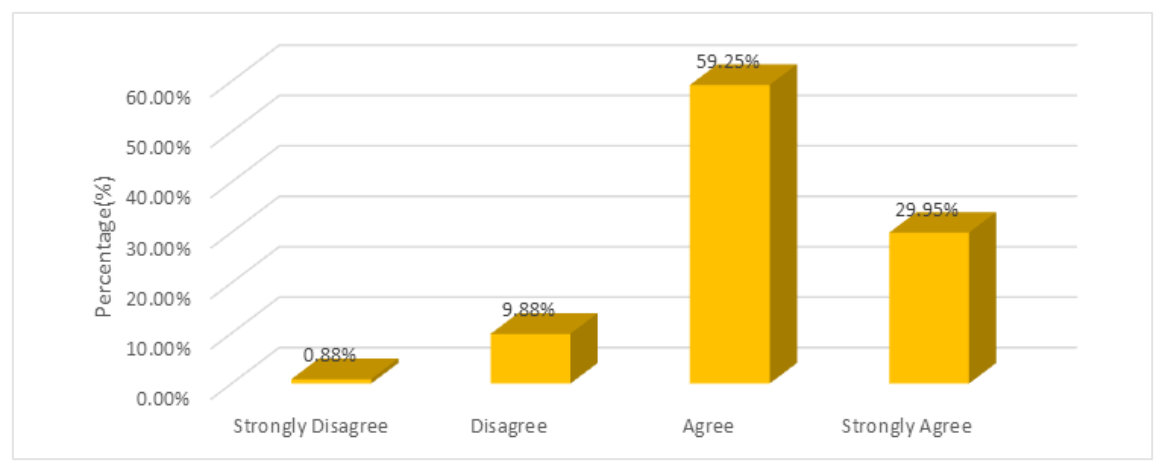

Fig. 1. Graph of Ease of Use Google Classroom in Mathematics Learning Lecturer in Primary School

Based on Figure 1. shows that $59.25 \%$ of students agreed to the ease of use of Google classroom in mathematics learning lecturers. Followed by $29.95 \%$ of students said they strongly agreed, $9.88 \%$ of students disagreed and only $0.88 \%$ stated strongly disagree with the ease of using google classroom in Mathematics Learning lecturer. As for the $59.25 \%$ of students who agreed, the majority stated that the online lecture platform using google classroom, the majority stated that it was more practical, simpler, and more cost-efficient compared to using other online lecture platforms.

This is the reason for the majority of students because, during lectures conducted online during this pandemic, students do not only use one type of platform. But students adjust the platforms used by lecturers including e-learning, Edmodo, youtube. While $9.88 \%$ of students who said they disagreed and $0.88 \%$ of students who strongly disagreed about the ease of use of google classroom in this lecture were because they preferred to conduct lectures using Whatsapp group because it was more practical than google classroom. However, these results indicate that the Mathematics Learning lectures in primary school using google classroom get good perceptions from students. This is following the results of research by Idad Suhada, Idad Suhada, Tuti Kurniati, Ading Pramadi, Milla Listiawati who stated that google classroom was effective enough to be used as an alternative to online learning [14]. 


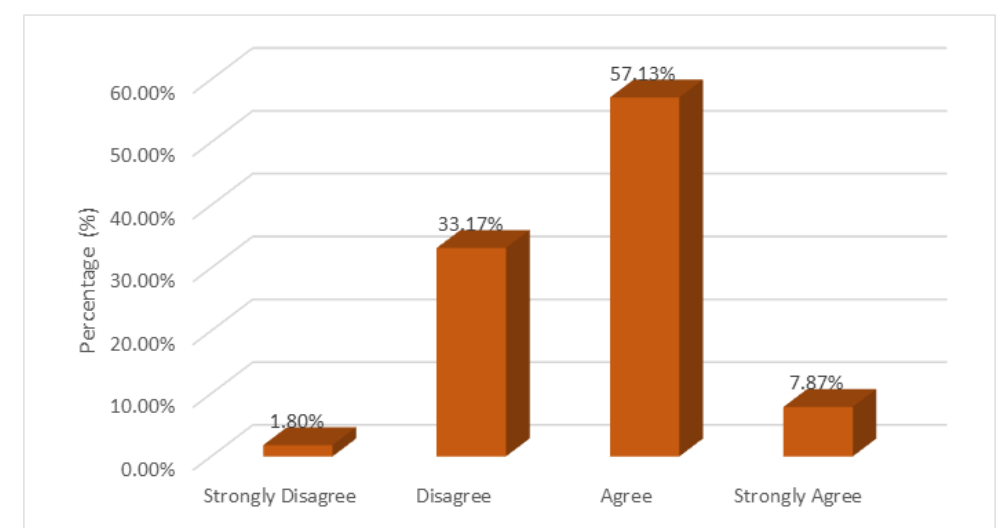

Fig. 2. Graph of Ease of Understanding of Material by Using Google Classroom in Mathematics Learning Lecturer in Primary School

Furthermore, in terms of ease of understanding of the material $57.13 \%$ of students stated agree and $7.87 \%$ of students who started strongly agreed that google classroom made it easier in terms of understanding the material because according to students during online lectures in Mathematics Learning lectures in primary school lecturers still provided feedbacks and feedback during the learning activities took place, while $33.1 \%$ of students expressed disagreement and the remaining $1.8 \%$ who strongly disagreed, students stated they preferred to carry out Mathematics Learning lectures in primary school face to face because it was easier to focus in learning, more understand the explanation and discussion directly and do not interfere with activities at home to help parents and because they do not have a special learning space.

However, according to the google classroom students as a whole have the perception of ease in understanding the material in the Mathematics Learning course in primary school it is under the results of Rana Saeed's research, Mostafa Al-Embran who stated that the google classroom can develop a better understanding for students and through google classroom makes the learning process interesting, effective, fosters motivation, foster an independent, active and creative learning attitude. Besides, this method can also improve students' understanding and learning outcomes [19, pp. 110-121].

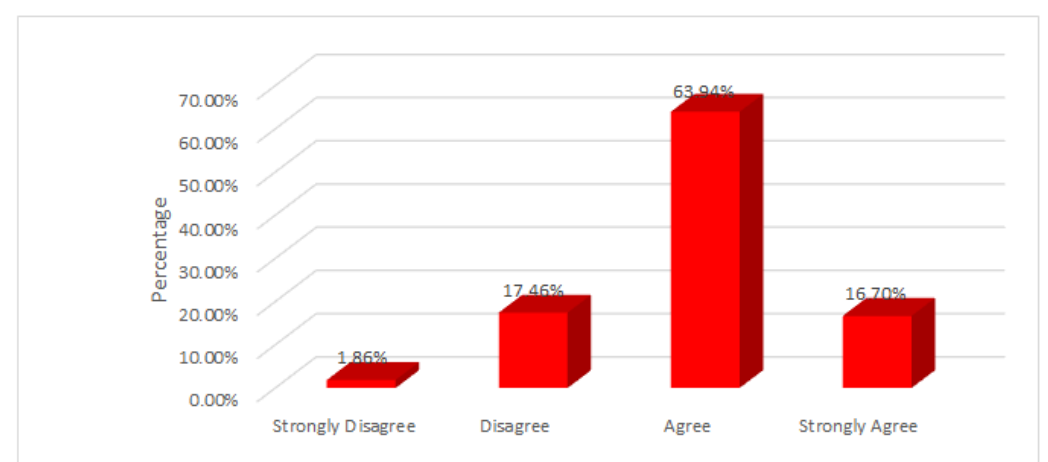

Fig. 3. Effectiveness Graph of Using Google Classroom in Mathematics Learning in Primary School According to Students 
Meanwhile, according to students in terms of the effectiveness of using google classroom in Mathematics Learning lecturers in primary school is effective. This can be demonstrated from the response of students who stated agreed to the effectiveness of google classroom that is equal to $63.94 \%$ and who stated very agree as much as $16.79 \%$. This is because students feel the benefits when using google classroom which is easier for students to collect assignments in the form of documents with both PDF and Word existences files and to be able to collect assignments more on time. This following google classroom is useful in facilitating the teaching and learning process, so students can use it easily whenever needed. Also, Google classroom makes it easy to create and provide assignments in the form of documents (paperless) or videos and discussions and online quizzes using the google form format with various types of questions [11, pp. 246-255].

However, $17.46 \%$ of students stated that they did not agree with the effectiveness of google classroom and $1.86 \%$ of students also strongly disagreed. This happens because students find it difficult to send assignments both in paperless and video content. Because the brand is in a difficult signal area so the network is unstable and often there is no delivery notification, so they don't know whether their duty has arrived or not. However, the percentage of $63.94 \%$ who agreed to shows that overall google classroom is effective enough to be used as an alternative to learning online [20, pp. 1-5].

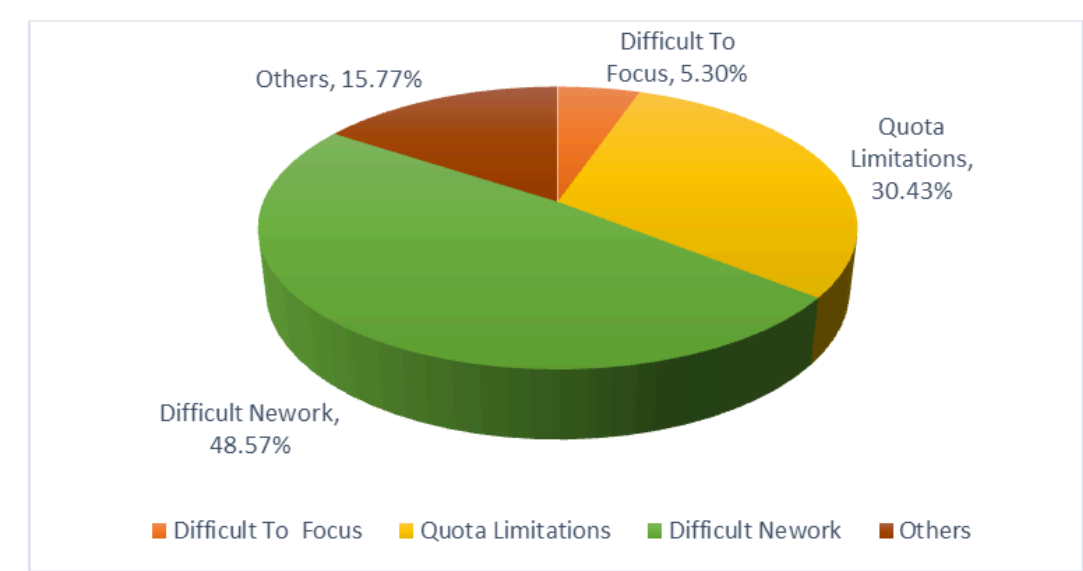

Fig. 4. Graph of Obstacles Experienced by Students in Mathematics Learning in Primary School

As for Figure 4, graphs show the results of respondents about the obstacles experienced by students in Mathematics Learning in primary school during the COVID-19 period, namely $48.57 \%$ of students stated that they were constrained in terms of difficult and unstable networks. This happens because it turns out there are many students who live in areas that are difficult to signal so that when conducting lectures they often experience signal disconnection. Furthermore, $30.43 \%$ of students stated that the constraints experienced were internet quota limitations. This is because one of them is because students while studying at home do not get pocket money from parents, economic difficulties, and the impact of reduced income of parents due to Corona Virus Disease (COVID-19).

Furthermore, $5.30 \%$ of students stated that it was difficult to focus because concentration was often disturbed by the home environment and activities helping parents at home. As for the $15.77 \%$ of students experiencing various kinds of constraints between signal and quota constraints, facilities, and infrastructure that support the learning process such as students do 
not have laptops so in completing assignments they only rely on mobile phones. Of course, this has resulted in suboptimal results in completing assignments, and students feeling bored and fed up with online learning.

\section{Conclusion}

From the discussion that has been explained, it can be concluded that google classroom provides ease of use, ease in understanding the material is used in Mathematics Learning in primary school even though in its implementation there are several obstacles including difficulty focusing, unstable network, limited quota, facilities and student infrastructure that have not all been met. However, in general, google classroom is effective in the process of teaching Mathematics Learning in primary school and can be used as an alternative in online learning. But it would be better if combined with other learning platforms and face-to-face learning.

\section{Reference}

[1] D. Cucinotta and M. Vanelli, "WHO declares COVID-19 a pandemic.," Acta BioMedica Atenei Parm., vol. 91, no. 1, pp. 157-160, 2020.

[2] E. U. Hanik, "SELF DIRECTED LEARNING BERBASIS LITERASI DIGITAL PADA MASA PANDEMI COVID-19 DI MADRASAH IBTIDAIYAH,” Elem. Islam. Teach. J., vol. 8, no. 1, pp. 183-208, 2020.

[3] A. Purwanto, R. Pramono, M. Asbari, C. C. Hyun, L. M. Wijayanti, and R. S. Putri, "Studi Eksploratif Dampak Pandemi COVID-19 Terhadap Proses Pembelajaran Online di Sekolah Dasar," EduPsyCouns J. Educ. Psychol. Couns., vol. 2, no. 1, pp. 1-12, 2020.

[4] A. Rusdiana, M. Sulhan, I. Z. Arifin, and U. A. Kamaludin, "Penerapan Model POE2WE Berbasis Blended Learning Google Classroom Pada Pembelajaran Masa WFH Pandemic Covid-19," 2020.

[5] H. Praherdhiono et al., Implementasi Pembelajaran di Era dan Pasca Pandemi Covid19. Seribu Bintang, 2020.

[6] "Home Learning jadi era Pembelajaran platform Edukasi Online di Indonesia." https://dailysocial.id.

[7] A. B. Kusuma and W. Astuti, "ANALISIS PENERAPAN MEDIA PEMBELAJARAN BAHASA ARAB BERBASIS APLIKASI GOOGLE CLASSROOM," Lahjah Arab. J. Bhs. Arab Dan Pendidik. Bhs. Arab, vol. 1, no. 1, pp. 67-89, 2020.

[8] A. Ghofur, "USING GOOGLE CLASSROOM ON INQUIRY BASED LEARNING TO IMPROVE STUDENTS'LEARNING PARTICIPATION,” J. Penelit. Pendidik., vol. 10 , no. $2,2018$.

[9] S. Iftakhar, "Google classroom: what works and how," J. Educ. Soc. Sci., vol. 3, no. 1, pp. 12-18, 2016.

[10] I. N. Mohd Shaharanee, J. Jamil, and S. S. Mohamad Rodzi, "The application of Google Classroom as a tool for teaching and learning," J. Telecommun. Electron. Comput. Eng., vol. 8, no. 10, pp. 5-8, 2016. 
[11] A. Muslik, "Google Classroom sebagai Alternatif Digitalisasi Pembelajaran Matematika di Era Revolusi Industri 4.0," Andragogi J. Diklat Tek. Pendidik. Dan Keagamaan, vol. 7, no. 2, pp. 246-255, 2019.

[12] G. K. Putri and Y. A. S. Dewi, "Pengaruh Model Pembelajaran Jarak Jauh Berbasis Google Classroom," AL-Fikr. J. Studi Ilmu Pendidik. Dan Keislam., vol. 2, no. 1, pp. 60-79, 2019.

[13] S. Sukmawati, "Implementasi Pemanfaatan Google Classroom Dalam Proses Pembelajaran Online di Era Industri 4.0,” J. Kreat. Online, vol. 8, no. 1.

[14] I. Suhada, T. Kurniati, A. Pramadi, and M. Listiawati, "Pembelajaran daring berbasis Google Classroom mahasiswa pendidikan biologi pada masa wabah Covid-19," Digit. Libr. UIN Sunan Gunung Djati, pp. 1-10, 2020.

[15] H. Hikmatiar, D. Sulisworo, and M. E. Wahyuni, "Utilization of Google ClassroomBased Learning Management System in Learning," J. Pendidik. Fis., vol. 8, no. 1, pp. 78-86, 2020.

[16] N. Nirfayanti and N. Nurbaeti, "Pengaruh Media Pembelajaran Google Classroom Dalam Pembelajaran Analisis Real Terhadap Motivasi Belajar Mahasiswa," Prox. J. Penelit. Mat. Dan Pendidik. Mat., vol. 2, no. 1, pp. 50-59, 2019.

[17] R. A. S. Al-Maroof and M. Al-Emran, "Students acceptance of Google classroom: An exploratory study using PLS-SEM approach," Int. J. Emerg. Technol. Learn. IJET, vol. 13, no. 06, pp. 112-123, 2018.

[18] I. Farida, R. Rahmawati, R. Aisyah, and I. Helsy, "Pembelajaran kimia sistem daring di masa pandemi Covid-19 bagi generasi Z," KTI Massa WHF Pandemi Covid-19, 2020.

[19] S. Maskar and E. Wulantina, "Persepsi Peserta Didik terhadap Metode Blended Learning dengan Google Classroom," INOMATIKA, vol. 1, no. 2, pp. 110-121, 2019.

[20] R. Rumyeni, "Communication Effectiveness of Online Media Google Classroom in Supporting the Teaching and Learning Process at Civil Engineering University of Riau," PhD Thesis, Riau University, 2017. 